\title{
Wpływ infrastruktury na zachowania kierowców na przejściach dla pieszych na przykładzie Warszawy i Radomia
}

\author{
Maciej Sulmicki
}

\section{STRESZCZENIE}

W 2019 r. przeprowadzone zostały badania wpływu rozwiązań infrastrukturalnych na przejściach dla pieszych i przejazdach dla rowerzystów na zachowania kierowców. Celem ramowym przeprowadzonych badań była weryfikacja trafności zapisów zawartych w dokumentach strategicznych i planistycznych województwa mazowieckiego odnoszących się do bezpieczeństwa ruchu drogowego. Lokalizacje w Warszawie i Radomiu zostały dobrane w taki sposób, aby uwzględnione zostały wszystkie wymienione w Planie zagospodarowania przestrzennego województwa mazowieckiego rodzaje uspokojenia ruchu mające służyć poprawie bezpieczeństwa i dotyczące bezpośrednio przejść dla pieszych. Jednocześnie pod uwagę brane były takie czynniki jak przekrój jezdni, układ skrzyżowania i sygnalizacja świetlna.

Podczas badań obserwowano zachowania kierowców względem niezmotoryzowanych oraz te, które determinowały możliwość szybkiego zareagowania na pojawienie się niezmotoryzowanego uczestnika ruchu. Badania były prowadzone z punktów obserwacyjnych oddalonych od skrzyżowania, by nie wpływać na zachowanie uczestników ruchu. Na podstawie co najmniej trzydziestominutowych obserwacji w terenie oraz późniejszej analizy nagrań notowano, czy: kierowca zatrzymuje się przed przejściem, wjeżdża przed lub za niezmotoryzowanego, zatrzymuje się na przejściu, wjeżdża szybko na przejście. $W$ wybranych lokalizacjach analizowano również, czy kierowca rozgląda się przed wjazdem na przejście, jednak $w$ większości miejsc nie było to możliwe ze względu na duże natężenie ruchu i/lub nieodpowiednią widoczność. Obserwacje w Radomiu zostały przeprowadzone przez Sebastiana Pawłowskiego i Łukasza Zaborowskiego z Mazowieckiego Biura Planowania Regionalnego, Oddziału Terenowego w Radomiu.

Wyniki badań wskazuja, że na niebezpieczne zachowania kierowców mają wpływ: przekrój jezdni na przejściu dla pieszych, obecność przejazdów dla rowerzystów i zasady pierwszeństwa, fizyczne środki uspokojenia ruchu oraz sygnalizacja świetlna. Wykazano, że nieskutecznym rozwiązaniem jest powierzchnia wyłączona z ruchu jedynie za pomocą oznakowania poziomego oraz czerwone światło z dopuszczonym warunkowym prawoskrętem (zieloną strzałką), które traktowane jest jako zielone światło.

Badania terenowe potwierdziły słuszność zapisów zawartych w dokumentach strategicznych i planistycznych województwa mazowieckiego, jak też konieczność ich szerszego stosowania. Analiza wyników pozwoliła wykazać konkretne zależności pomiędzy różnymi parametrami rozwiązań a ich wpływem na zachowania kierowców, co stanowi uzupełnienie prowadzonych wcześniej badań lokalnych oraz na poziomie krajowym, przeprowadzonych w $2018 \mathrm{r}$.

Słowa kluczowe: bezpieczeństwo ruchu drogowego, przejścia dla pieszych, niechronieni uczestnicy ruchu, uspokojenie ruchu 


\section{Wprowadzenie}

Polska jest jednym z najbardziej niebezpiecznych państw w Unii Europejskich pod względem prawdopodobieństwa śmierci na drodze. W przeliczeniu na mieszkańca, na polskich drogach ginie o połowę więcej osób niż średnio w Unii Europejskiej [Skoczyński, Wacowska-Ślęzak 2019, s. 4, rys. 3]. Niemal jedna trzecia zabitych to piesi, co oznacza, że w liczbach bezwzględnych, w Polsce ginie najwięcej pieszych spośród spośród 27 państw UE oraz Wielkiej Brytanii. Liczba pieszych zabitych w Polsce jest niemal dwukrotnie wyższa niż w Niemczech, mimo że ludność Polski jest ponad dwukrotnie mniejsza; ofiar śmiertelnych w Polsce jest dwuipółkrotnie więcej niż w o 1 / 4 większej Hiszpanii, kraju „południowego temperamentu”. Wskazuje to na szereg problemów, poczynając od wadliwych przepisów, przez ich nieefektywną egzekucję, po niewłaściwie projektowaną i wykonywaną infrastrukturę.

Kluczowym elementem infrastruktury z punktu widzenia bezpieczeństwa pieszych sa przecięcia ciagów pieszych i kołowych, czyli przejścia dla pieszych. Tam właśnie najbardziej prawdopodobne jest zetknięcie się samochodu i niezmotoryzowanego. Przejście dla pieszych powinno z założenia stanowić miejsce, gdzie możliwe jest bezpieczne przekroczenie jezdni. Podkreślaja to przepisy wskazujące, że na przejściu pieszy ma pierwszeństwo ${ }^{1}$, choć powinien zachować na nim szczególną ostrożność, analogicznie do kierowcy zbliżającego się do przejścia.

Zgodnie z art. 26 Prawa o ruchu drogowym, „Kierujący pojazdem, zbliżając się do przejścia dla pieszych, jest obowiązany zachować szczególną ostrożność i ustapić pierwszeństwa pieszemu znajdującemu się na przejściu”. Należy przy tym podkreślić, że ustąpienie pierwszeństwa jest zdefiniowane jako „powstrzymanie się od ruchu, jeżeli ruch mógłby zmusić (...) pieszego - do zatrzymania się, zwolnienia lub przyspieszenia kroku". Zakazane jest również wyprzedzanie i omijanie innych pojazdów na przejściu, jak też zatrzymywanie się na przejściu (za linią warunkowego zatrzymania).

Zachowanie ostrożności przez kierowcę szczególnie szwankuje w Polsce. Potwierdza to badanie wykonane na zlecenie Krajowej Rady Bezpieczeństwa Ruchu Drogowego w ostatnich czterech miesiącach 2018 r. Podczas gdy „w trakcie prowadzonych badań nie stwierdzono znacznych problemów związanych z nieprawidłowymi zachowaniami pieszych", to 85-90\% kierowców przekraczało dozwolony limit prędkości, dojeżdżając do wyznaczonego przejścia. Widoczna jest przy tym korelacja między przekrojem jezdni a prędkością [Ministerstwo Infrastruktury, Sekretariat KRBRD 2019, s. 77].

Badania prowadzone w poprzednich dekadach w innych państwach, głównie Wielkiej Brytanii i Skandynawii, wskazują na zależność między zachowaniem kierowców na przej-

\footnotetext{
${ }^{1} \mathrm{~W}$ trakcie pisania artykułu trwał proces legislacyjny służący ujednoznacznieniu i ujednoliceniu przepisów w tym zakresie poprzez doprecyzowanie w Prawie o Ruchu Drogowym, że kierowca powinien ustapić pieszemu już wchodzącemu na przejście. W trakcie badań obowiązywało rozporządzenie z dnia 31 lipca 2002 r. w sprawie znaków i sygnałów drogowych, zgodnie z którym „Kierujący pojazdem zbliżający się do miejsca oznaczonego znakiem D-6, D-6a albo D-6b [przejście dla pieszych lub przejazd dla rowerzystów] jest obowiązany zmniejszyć prędkość tak, aby nie narazić na niebezpieczeństwo pieszych lub rowerzystów znajdujących się w tych miejscach lub na nie wchodzących lub wjeżdżających."
} 
ściach a jego fizycznym zagospodarowaniem. Poprawa bezpieczeństwa została odnotowana w przypadku stosowania wyniesionych przejść i azyli, jak też ograniczania szerokości jezdni. Jednocześnie widoczny był negatywny wpływ sygnalizacji świetlnej na bezpieczeństwo pieszych na skrzyżowaniach z kolizyjnymi fazami, np. możliwością skrętu w prawo na zielonym świetle na przejście, na którym piesi jednocześnie mają zielone światło [Vaa 2006, s. 4]. Badania w Polsce skupiały się na związku zachowań kierowców z przekrojem jezdni (liczba pasów) i obecnością sygnalizacji, pomijając obecność fizycznego uspokojenia ruchu i promieni łuków w przypadku relacji skrętnych [Budzyński, Jamroz, Mackun 2017; Ministerstwo Infrastruktury, Sekretariat KRBRD 2019, s. 9].

Wyniki ww. badań KRBRD zostały upublicznione w lipcu 2019 r. W tym samym czasie pracownicy Mazowieckiego Biura Planowania Regionalnego przeprowadzali w Warszawie i Radomiu² badania służące określeniu wpływu rozwiązań infrastrukturalnych zastosowanych na przejściach dla pieszych i przejazdach dla rowerzystów na zachowania kierowców. Pod uwagę brane były takie czynniki jak przekrój jezdni, uspokojenie ruchu i sygnalizacja świetlna, a wyniki badań zostały przedstawione na X Kongresie Mobilności Aktywnej we wrześniu 2019 r. i posłużyły jako punkt wyjścia dla niniejszego artykułu. Celem ramowym przeprowadzonych badań była weryfikacja trafności zapisów zawartych w wojewódzkich dokumentach strategicznych i planistycznych odnoszących się do bezpieczeństwa ruchu drogowego.

\section{Bezpieczeństwo ruchu drogowego w dokumentach województwa mazowieckiego}

Przyjęta w 2013 r. Strategia rozwoju województwa mazowieckiego do 2030 roku. Innowacyjne Mazowsze wyraźnie podkreśla znaczenie funkcjonalnej i bezpiecznej dla niezmotoryzowanych infrastruktury w systemie transportowym. W diagnozie obszaru „Przestrzeń i transport” wskazano, że "o wpływie drogi na dostępność obszaru decydują takie elementy, jak infrastruktura piesza i rowerowa oraz dostosowanie jej do potrzeb osób starszych bądź o ograniczonej sprawności ruchowej”. W analizie SWOT sformułowano wyzwanie „zwiększenie znaczenia transportu zbiorowego, rowerowego i ruchu pieszego w systemie transportowym”, a jako szansę zidentyfikowano „inwestycje drogowe stwarzające możliwość zwiększenia ruchu pieszego i rowerowego przez uwzględnianie potrzeb tych grup użytkowników przy projektowaniu i (prze)budowie dróg". Niewatpliwie, jedną z tych potrzeb jest możliwość bezpiecznego przekraczania jezdni.

Na poziomie działań sformułowano kierunek działań „Rozwój form transportu przyjaznych dla środowiska i mieszkańców" oraz, w jego ramach, dwa działania istotne z punktu widzenia bezpieczeństwa na przejściach dla pieszych i przejazdach dla rowerzystów:

- zwiększenie udziału ruchu pieszego i rowerowego w ogóle podróży,

- podniesienie poziomu bezpieczeństwa ruchu drogowego, w tym poprzez strefowe uspokojenie ruchu na obszarach zabudowanych.

\footnotetext{
${ }^{2}$ W latach 2017-2019 w obu miastach miało miejsce 45\% wypadków z udziałem pieszych w województwie.
} 
Powyższe zapisy wskazują na dążenie Samorządu Województwa Mazowieckiego do zapewnienia warunków do efektywnego i bezpiecznego poruszania się niezmotoryzowanych. Kwestia bezpieczeństwa została rozwinięta w Planie zagospodarowania przestrzennego województwa mazowieckiego (PZPWM). W dokumencie przyjętym w $2018 \mathrm{r}$. zapisano postulat działań dotyczacych podnoszenia poziomu bezpieczeństwa na drogach przez:

- realizację chodników, dróg dla rowerów, przejść dla pieszych i przejazdów dla rowerzystów;

- działania poprawiające bezpieczeństwo ruchu, w tym m.in.: strefowanie prędkości pojazdów, fizyczne środki uspokajania ruchu (progi zwalniające, wyniesione przejścia dla pieszych, azyle dla pieszych, wyniesione skrzyżowania, małe ronda).

W części dotyczącej miejskiego obszaru funkcjonalnego Warszawy zawarto ponadto postulat zwiększenia udziału ruchu pieszego i rowerowego. Jest to zapis spójny ze Strategia rozwoju Obszaru Metropolitalnego Warszawy do roku 2030, w której podkreślono potrzebę stosowania hierarchii transportu właściwej dla współczesnych procesów rozwojowych metropolii, tj. stawiającą ruch pieszy i rowerowy oraz komunikacje publiczna przed motoryzacja indywidualna.

Zapisem, którego dotyczyły bezpośrednio przeprowadzone badania, był zawarty w PZPWM postulat poprawy bezpieczeństwa ruchu drogowego poprzez uspokajania ruchu za pomocą wyniesionych przejść dla pieszych i całych skrzyżowań, azyli dla pieszych oraz małych rond. Efektywność stosowania takich rozwiązań, zwłaszcza w kontekście zapisów dotyczących poprawy bezpieczeństwa i zwiększenia udziału ruchu pieszego i rowerowego, została zweryfikowana w terenie. Zbadane zostały zachowania kierowców w 20 punktach przecięcia jezdni z chodnikami, a w niektórych przypadkach również drogami dla rowerów.
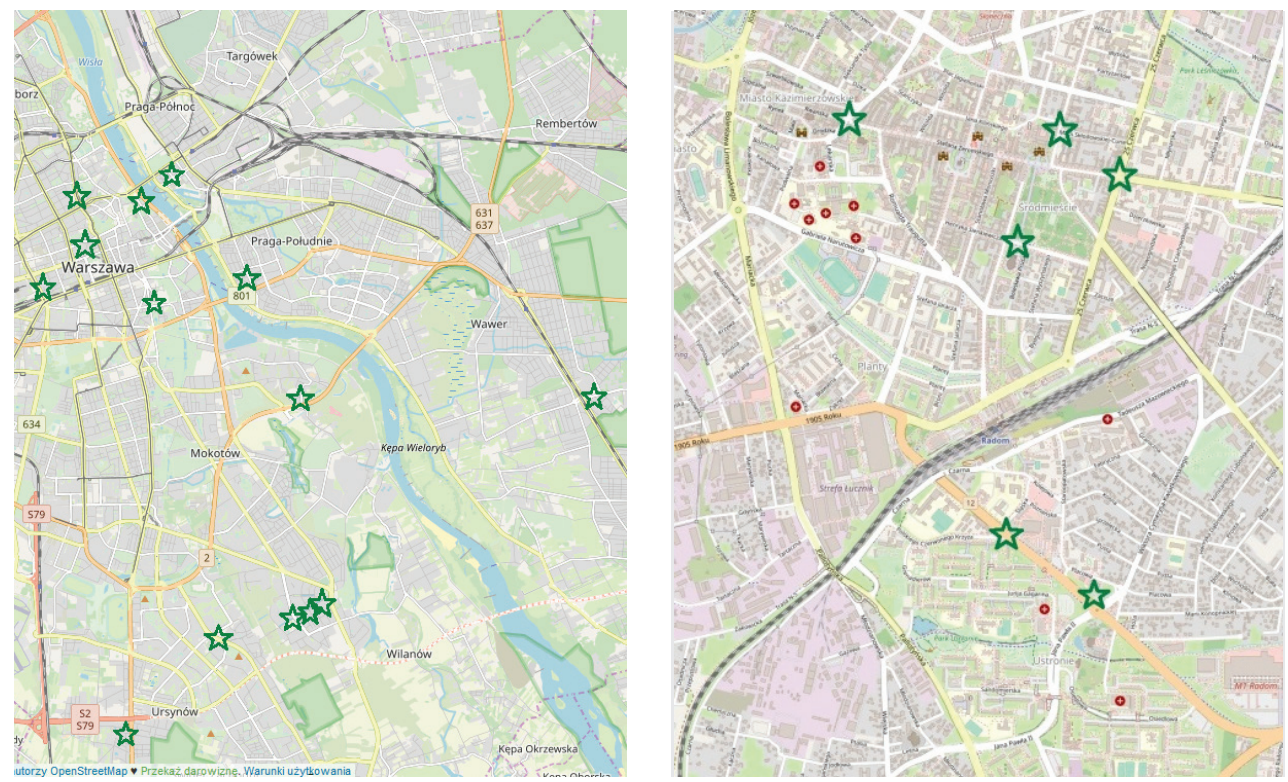

Ryc. 1. Lokalizacje badanych przejść w Warszawie (po lewej) i Radomiu (po prawej)

Źródło podkładu: Open Street Map 


\section{Charakterystyka analizowanych miejsc}

Do badań wytypowano 20 przejść/ skrzyżowań, z czego 14 znajdowało się w Warszawie, a 6 w Radomiu (ryc. 1). Pod względem rodzajów infrastruktury, obserwacji i analizie poddano:

- 6 przejść usytuowanych poza skrzyżowaniami jezdni,

- 6 przejść przez skrzyżowania trójramienne (typu „T") bez świateł,

- 5 przejść przez skrzyżowania ze światłami,

- 3 przejścia przez ramię ronda.

Pozwoliło to na zbadanie zachowania kierowców względem niezmotoryzowanych na następujących rodzajach skrzyżowań ciągów pieszych i drogowych:

- wyniesionych przejściach dla pieszych,

- przejściach poza skrzyżowaniem wyposażonych w azyl (wyspę),

- przejściach poza skrzyżowaniem bez azylu (wyspy),

- wyniesionych skrzyżowaniach,

- małych i średnich rondach,

- $\quad$ skrzyżowaniach i przejściach z sygnalizacją świetlna, z zastosowaniem zielonej strzałki i bez możliwości warunkowego skrętu na czerwonym świetle.

Tym samym lokalizacje zostały dobrane w taki sposób, aby uwzględnione zostały wszystkie wymienione w Planie zagospodarowania przestrzennego województwa mazowieckiego rodzaje uspokojenia ruchu mające służyć poprawie bezpieczeństwa i dotyczące bezpośrednio przejść dla pieszych. Zestawienie badanych przejść przedstawiono w tabeli 1.

Tabela 1. Zestawienie przejść dla pieszych i przejazdów dla rowerzystów

\begin{tabular}{|l|l|c|l|}
\hline Miejscowość & Ulica/skrzyżowanie & Przekrój & \multicolumn{1}{|c|}{ Typ przejścia/skrzyżowania } \\
\hline Warszawa & Grzybowska 5 & $2 \times 2$ & Przejście poza skrzyżowaniem z azylem \\
\hline Warszawa & Paryska 14 i 16 & $2 \times 1$ & $\begin{array}{l}\text { Przejście (i przejazd) poza skrzyżowaniem } \\
\text { z azylem }\end{array}$ \\
\hline Radom & Sienkiewicza 16 & $1 \times 2$ & Przejście poza skrzyżowaniem, wyniesione \\
\hline Radom & Polska 33 & $1 \times 2$ & $\begin{array}{l}\text { Przejście (i przejazd) poza skrzyżowaniem } \\
\text { w poziomie jezdni }\end{array}$ \\
\hline Warszawa & $\begin{array}{l}\text { Teodorowicza / } \\
\text { Klimczaka }\end{array}$ & $1 \times 2$ & $\begin{array}{l}\text { Przejście poza skrzyżowaniem w poziomie } \\
\text { jezdni }\end{array}$ \\
\hline Radom & $\begin{array}{l}\text { Niedziałkowienne (typu „ } \\
\text { t Skłodón }\end{array}$ \\
\hline
\end{tabular}

\footnotetext{
${ }^{3}$ Przejście jest za skrzyżowaniem typu "T", lecz trzecie ramię jest jednokierunkowe, bez możliwości ruchu w kierunku przejścia dla pieszych.
} 


\begin{tabular}{|c|c|c|c|}
\hline Miejscowość & Ulica/skrzyżowanie & Przekrój & Typ przejścia/skrzyżowania \\
\hline Warszawa & $\begin{array}{l}\text { Matejki / Al. } \\
\text { Ujazdowskie }\end{array}$ & $1 \times 2$ & Trójramienne (typu „, $\left.\mathrm{T}^{\prime \prime}\right) \mathrm{w}$ poziomie jezdni \\
\hline Warszawa & $\begin{array}{l}\text { Nowolipki / } \\
\text { Andersa }\end{array}$ & $1 \times 3$ & $\begin{array}{l}\left.\text { Trójramienne (typu „, } \mathrm{T}^{\prime \prime}\right) \mathrm{w} \text { poziomie jezdni } \\
\text { z powierzchnia wyłączoną z ruchu za } \\
\text { pomocą oznakowania poziomego }\end{array}$ \\
\hline Warszawa & $\begin{array}{l}\text { Wędrowców / } \\
\text { Puławska }\end{array}$ & $1 \times 2$ & $\begin{array}{l}\text { Trójramienne (typu „,T”) z wyniesionym } \\
\text { przejściem i przejazdem }\end{array}$ \\
\hline Warszawa & $\begin{array}{l}\text { Srebrna / } \\
\text { Towarowa }\end{array}$ & $1 \times 2$ & $\begin{array}{l}\text { Trójramienne (typu „T") z wyniesionym } \\
\text { przejściem i przejazdem }\end{array}$ \\
\hline Warszawa & $\begin{array}{l}\text { Klimczaka / } \\
\text { Sarmacka }\end{array}$ & $2 \times 1$ & Małe rondo jednopasmowe (średnica $24 \mathrm{~m}$ ) \\
\hline Warszawa & $\begin{array}{l}\text { Żegańska / } \\
\text { Dworcowa }\end{array}$ & $2 \times 2$ & $\begin{array}{l}\text { Średnie rondo dwupasmowe (średnica } \\
42 \mathrm{~m} \text {, wyspa } 25 \mathrm{~m} \text { ) }\end{array}$ \\
\hline Radom & Rondo Dmowskiego & $2 \times 2$ & $\begin{array}{l}\text { Średnie rondo dwupasmowe (średnica } \\
43 \mathrm{~m} \text {, wyspa } 28 \mathrm{~m} \text { ) }\end{array}$ \\
\hline Warszawa & $\begin{array}{l}\text { Nowy Zjazd } \\
\text { / Wybrzeże } \\
\text { Kościuszkowskie }\end{array}$ & $3+1$ & $\begin{array}{l}\text { Trójramienne (typu ,"T") z zieloną strzałka, } \\
\text { z azylem }\end{array}$ \\
\hline Warszawa & $\begin{array}{l}\text { Sierakowskiego / } \\
\text { al. Solidarności }\end{array}$ & $1 \times 4$ & $\begin{array}{l}\text { Trójramienne (typu „"T") z zieloną strzałka, } \\
\text { bez azylu }\end{array}$ \\
\hline Warszawa & $\begin{array}{l}\text { al. Rzeczypospolitej } \\
\text { / Klimczaka }\end{array}$ & $2 \times 2$ & Czteroramienne z zieloną strzałka, z azylem \\
\hline Warszawa & Nugat / Rosoła & $2 \times 2$ & Czteroramienne z zieloną strzałka, z azylem \\
\hline Radom & $\begin{array}{l}25 \text { Czerwca / } \\
\text { Żeromskiego }\end{array}$ & $2+3$ & Czteroramienne z zieloną strzałka, z azylem \\
\hline Radom & Grzecznarowskiego & $2 \times 2$ & $\begin{array}{l}\text { Przejście z sygnalizacją poza } \\
\text { skrzyżowaniem }\end{array}$ \\
\hline
\end{tabular}

Źródło: opracowanie własne

Podczas badań obserwowano zachowania kierowców względem niezmotoryzowanych oraz te, które determinowały możliwość odpowiednio szybkiego zareagowania na pojawienie się niezmotoryzowanego uczestnika ruchu. Badania były prowadzone z punktów obserwacyjnych oddalonych od skrzyżowania, by nie wpływać na zachowanie uczestników ruchu. Na podstawie co najmniej trzydziestominutowych obserwacji w terenie oraz późniejszej 
analizy nagrań notowano, czy: kierowca zatrzymuje się przed przejściem, wjeżdża przed lub za niezmotoryzowanego, zatrzymuje się na przejściu, wjeżdża szybko na przejście ${ }^{4}$. W wybranych lokalizacjach analizowano również, czy kierowca rozgląda się przed wjazdem na przejście, jednak w większości miejsc nie było to możliwe ze względu na duże natężenie ruchu i/lub nieodpowiednią widoczność.

\section{Wyniki badań}

\subsection{Przejścia dla pieszych poza skrzyżowaniami}

Przejścia poza skrzyżowaniami bez sygnalizacji świetlnej zostały wybrane, biorąc pod uwage przede wszystkim przekrój jezdni, zastosowanie azylu dla pieszych i wyniesienie przejścia. W związku z tym zbadanych zostało 5 przejść, w tym 3 w Warszawie i 2 w Radomiu: - $1 \mathrm{z}$ azylem przez jezdnię czteropasmowa (przekrój na przejściu: dwa razy dwa pasy ruchu $\left.^{5}-2 \times 2\right)$,

- 1 z azylem przez jezdnię dwupasmowa (przekrój 2x1),

- $\quad 2$ z wyniesionym przejściem przez jezdnię dwupasmowa (przekrój 1x2),

- $\quad 2$ bez elementów fizycznego uspokojenia ruchu przez jezdnię dwupasmową bez azylu (przekrój 1x2).

Badania wskazały znaczące zróżnicowanie zachowań kierowców, zależne przede wszystkim od przekroju jezdni i wyniesienia przejścia do poziomu chodnika, przez co pełni ono jednocześnie funkcję progu spowalniającego. Widoczny był również wpływ widoczności na przejściu na czujność kierowców.

Przejście przy Grzybowskiej 5 prowadzi przez dwa pasy ruchu o szerokości 3,0 m w kierunku wschodnim i jeden pas ruchu o szerokości 5,5 m w kierunku zachodnim. Tym samym w obu kierunkach możliwe jest wyprzedzanie na przejściu, acz w kierunku zachodnim zdecydowanie rzadziej dwa samochody zbliżają się do przejścia jednocześnie. Jezdnie rozdzielone są azylem o szerokości 1,6 metra - mniejszej od minimalnych wymaganych prawem dwóch metrów, a przed i za przejściem - płotem rozdzielającym jezdnie. Widoczność jest dobra, ograniczona jedynie przez drzewa przed przejściem z jednej strony. Przejście jest dodatkowo oznakowane znakiem T-27, wskazującym, że przejście jest uczęszczane przez dzieci. Ruch pieszych na przejściu jest duży, jako że znajduje się ono w gęsto zabudowanym obszarze śródmiejskim.

\footnotetext{
${ }^{4}$ Szybkość była przy tym badana subiektywnie, z punktu widzenia niezmotoryzowanych, bez pomiaru prędkości.

${ }_{5}^{5}$ Jezdnia na wysokości badanego przejścia (przy ul. Grzybowskiej 5) ma wytyczone trzy pasy ruchu: dwa na jezdni południowej i jeden na północnej. Jednak na jezdni północnej drugi pas ruchu kończy się dwadzieścia metrów przed przejściem, a jezdnia zachowuje przekrój umożliwiający wyprzedzanie na przejściu (5,5 m). Przekrój został zatem zakwalifikowany jako 2x2.
} 
Domyślnym trybem jazdy kierowców w okolicach przejścia była jazda szybka. Nie zaobserwowano również rozglądania się ze strony zbliżających się kierowców, jeżeli na przejściu lub w jego bezpośrednim sąsiedztwie nie znajdował się pieszy. W przypadku, gdy na przejściu znajdował się pieszy lub się do niego zbliżał, tylko 55\% kierowców zatrzymywało się przed przejściem, a 7\% na przejściu. 30\% kierowców wjeżdżało na przejście szybko, mimo obecności niezmotoryzowanego, w tym 17\% ogółu wjeżdżało szybko przed pieszego będącego na przejściu lub wchodzącego na nie (ryc. 2 i 3). Dodatkowo, 38\% kierowców wjeżdżało za pieszego, nie czekając aż zejdzie on z pasów. Pozytywną obserwacją był brak dłuższego oczekiwania na przejście - ruch niezmotoryzowanych odbywał się w miarę płynnie. Dodatkowo widoczny był efekt uspokojenia ruchu w przypadku samochodów parkujących na jezdni za przejściem, wymuszających zwolnienie i esowanie toru jazdy przez pojazdy jadące prawą strona jezdni.
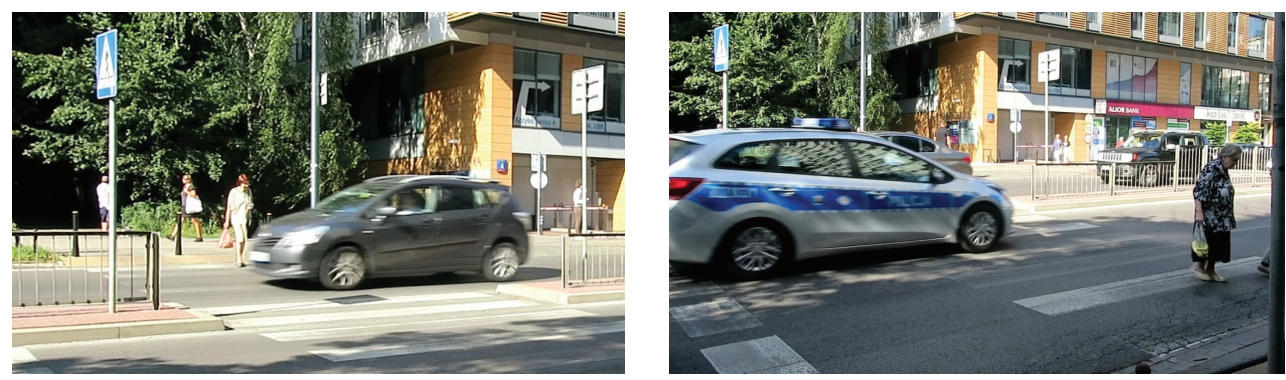

Ryc. 2 i 3 . Zachowania kierowców wobec pieszych na przejściu przez ul. Grzybowską w Warszawie wjazd na przejście przed i za pieszymi

Fot. M. Sulmicki

Przejścia dla pieszych i przejazdy dla rowerzystów przy ul. Paryskiej 14 i 16 prowadza przez dwa pasy ruchu o szerokości 4,5 m, po jednym w każdym kierunku, rozdzielone trzymetrowa wyspa (ryc. 4). Między oddalonymi o ok. $40 \mathrm{~m}$ przejściami nad jezdnią znajduje się wiadukt Trasy Łazienkowskiej, którego podpory ograniczaja widoczność na drugim przejściu w każdym kierunku. Przed azylami znajdują się pasy

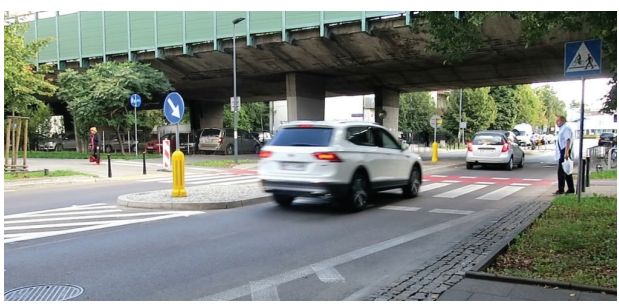

Ryc. 4. Przejście i przejazd przy ul. Paryskiej 14 w Warszawie

Fot. M. Sulmicki do parkowania i jezdnia nieznacznie odgina się po ich zakończeniu, by ominąc azyl, przy czym poza samym azylem powierzchnie wyłączone z ruchu zostały oznakowane jedynie za pomocą farby. Ruch pieszych i rowerzystów był umiarkowany.

Szerokość pasów umożliwia wymijanie pieszych znajdujących się na przejściu, jednak różnica szerokości 1-1,5 m względem Grzybowskiej znacząco ograniczyła skłonności kierowców w tym zakresie. Widoczna była również większa czujność ze strony kierowców ja- 
dących od strony wcześniejszego przejścia i filarów wiaduktu. Na przejściu północnym badano, czy kierowcy rozglądali się w wyraźny sposób przed wjazdem na przejście i przejazd - takie zachowanie zaobserwowano u 57\% z nich, niezależnie od tego, czy w polu widzenia był niezmotoryzowany. W przypadku, gdy na przejściu znajdował się pieszy/rowerzysta lub się do niego zbliżał, 71\% kierowców zatrzymywało się przed przejściem, a 4\% na przejściu. 14\% kierowców wjeżdżało na przejście szybko, mimo obecności niezmotoryzowanego, w tym $4 \%$ ogółu wjeżdżało szybko przed niezmotoryzowanego będącego na przejściu lub wchodzącego na nie. Dodatkowo, 13\% kierowców wjeżdżało za niezmotoryzowanego, nie czekając aż zejdzie on z pasów.

Przejście dla pieszych i przejazd dla rowerzystów przy ul. Polskiej 33 cechuje się podobnym układem, jako że biegnie wzdłuż wiaduktu Trasy Siekierkowskiej. Widoczność jest z jednej strony ograniczona nasypem i filarami wiaduktu, a z drugiej - drzewami i ogrodzeniem budynku. Po drugiej stronie wiaduktu również znajduje się przejście i przejazd, lecz ze względu na ograniczona widoczność przedmiotem obserwacji był tylko ten po północnej stronie. Jezdnia ma 6 m szerokości, a przed przejściem i przejazdem znajdują się znaki ostrzegawcze. Ruch niezmotoryzowanych był niewielki.

Mimo niewielkiego ruchu, głównie rowerowego, widoczna była wysoka ostrożność kierowców. $73 \%$ z nich wyraźnie rozglądało się, a $47 \%$ zatrzymywało się przed wjazdem na przejście i przejazd, niezależnie od tego, czy w polu widzenia znajdował się niezmotoryzowany. Kolejne 5\% zatrzymywało się na przejściu, w większości przypadków gdy rozglądali się, wjeżdżając i dostrzegli rowerzystę. Szybko na przejście wjeżdżało poniżej 15\% kierowców, z czego żaden nie robił tego w obecności niezmotoryzowanego. Nie zaobserwowano też wjazdu na przejście przed/za niezmotoryzowanego.

Podobne warunki występowały na przejściu przez ul. Wałową w Radomiu, gdzie widoczność od strony południowej ograniczona jest przez kamienice, a od północy ruch jest uspokojony jednopasmowym rondem. Jezdnia na wysokości przejścia ma przekrój ok. $7 \mathrm{~m}$, rozszerza się w kierunku ronda. $W$ tym przypadku przejście znajdowało się jednak w obszarze śródmiejskim, a natężenie ruchu pieszego było duże. Większe było również natężenie ruchu samochodowego.

Nie zaobserwowano szybkiej jazdy, śladowa była również liczba zatrzymujących się na przejściu dla pieszych. Zdecydowanie częściej niż na Polskiej obserwowano jednak wjazd przed pieszego wchodzacego lub czekającego na przejście (ponad 20\% kierowców), jak też będącego na przejściu (2\%). Kolejne 23\% kierowców wjeżdżało za niezmotoryzowanego.

Przejście przez ul. Sienkiewicza w Radomiu jest wyniesione do poziomu chodnika i łączy park z kościołem (ryc. 5). Widoczność od strony kościoła jest ograniczona przez

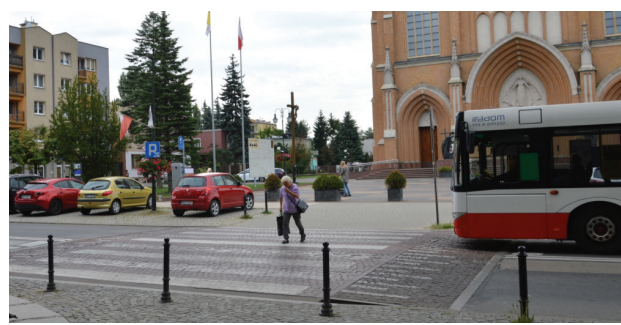

Ryc. 5. Przejście przy ul. Sienkiewicza 33 w Radomiu

Fot. S. Pawłowski 
miejsca do parkowania prostopadłego doprowadzone do samego przejścia. Przekrój jezdni wynosi $9 \mathrm{~m}$. Ruch pieszy był umiarkowany.

W tym przypadku nie zaobserwowano zatrzymywania się na przejściu, śladowa była również liczba wjeżdżających na nie szybko $(<1 \%)$. Znaczna szerokość jezdni skutkowała zaś częstym omijaniem pieszych na przejściu, poprzez wjeżdżanie zarówno przed, jak i za nich (łącznie 24\%).

Powyższe obserwacje potwierdzają zależność pomiędzy zachowaniami kierowców a przekrojem jezdni i fizycznymi środkami uspokojenia ruchu. Częstotliwość wjazdu na przejście z dużą prędkością mimo obecności niezmotoryzowanego była skorelowana z przekrojem jezdni, z wyjątkiem sytuacji, gdzie przejście wyniesione było do poziomu chodnika i pełniło funkcje progu spowalniającego (ryc. 6). Podobna zależność jest widoczna w przypadku częstotliwości wjazdu przed i za pieszego, przy czym w tym przypadku wyniesienie przejścia nie ma znaczenia (ryc. 7).

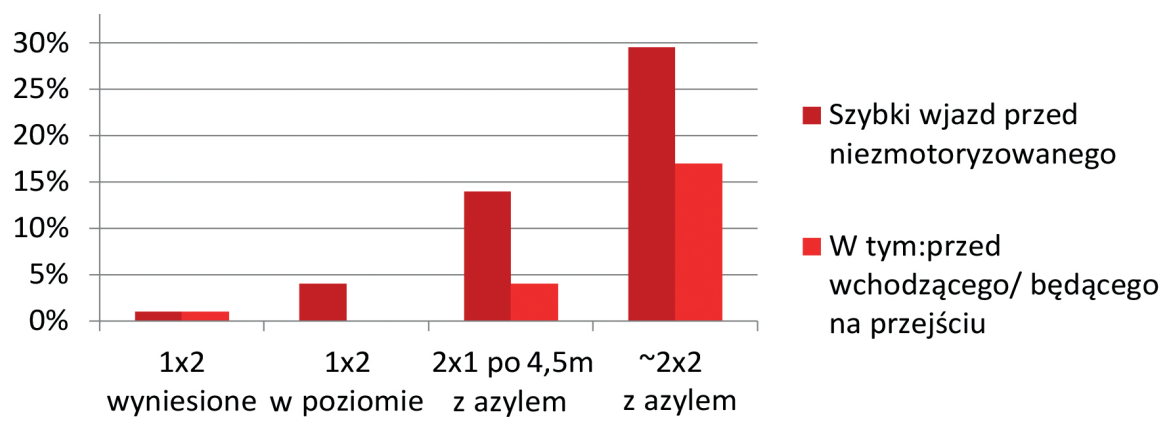

Ryc. 6. Częstotliwość szybkiego wjeżdżania na przejście w obecności niezmotoryzowanego przez jezdnie o różnym przekroju (liczba jezdni x liczba pasów) i wyposażeniu

Źródło: opracowanie własne

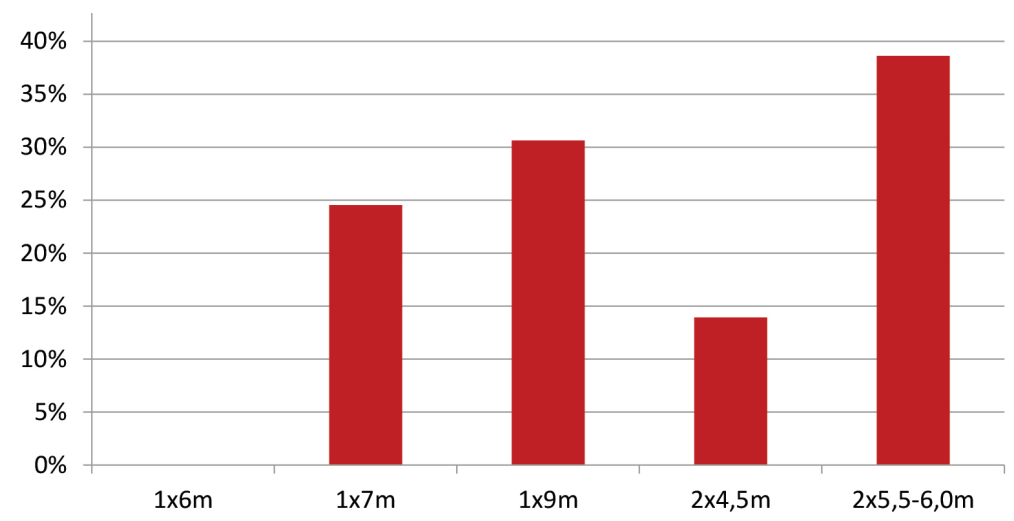

Ryc. 7. Częstotliwość wjazdu na przejście, na którym znajduje się niezmotoryzowany, w zależności od przekroju jezdni

Źródło: opracowanie własne 
Jako punkt odniesienia zbadano też jedno przejście z sygnalizacją świetlną - przez ul. Grzecznarowskiego 17 w Radomiu, by zweryfikować skuteczność świateł w dyscyplinowaniu zachowań kierowców. W trakcie 27 cykli, na żółtym i czerwonym świetle przejechało 47 samochodów, w tym 15 na czerwonym (w 55\% cykli) i 32 na żółtym (w 89\% cykli). Zmiana świateł i szeroki przekrój jezdni (3+2) zachęcały zatem do niebezpiecznych zachowań, w tym zwłaszcza przyspieszania przed przejściem.

\subsection{Przejścia dla pieszych poza skrzyżowaniami}

Przejścia przez skrzyżowania typu „T" bez sygnalizacji zostały wybrane, biorac pod uwagę przekrój jezdni oraz wyniesienie przejścia lub całego skrzyżowania do poziomu chodnika. W związku z tym do badań wybranych zostało 5 przejść przez ulice dwukierunkowe w Warszawie i $1 \mathrm{w}$ Radomiu:

- $1 \mathrm{w}$ poziomie jezdni przez 2 pasy ruchu (przejście i przejazd przez ul. Matejki wzdłuż Al. Ujazdowskich w Warszawie),

- $1 \mathrm{w}$ poziomie jezdni przez 3 pasy ruchu z malowanym „azylem” (przez ul. Nowolipki wzdłuż ul. Andersa w Warszawie),

- 2 wyniesione przez 2 pasy ruchu (przejście i przejazd przez ul. Wędrowców wzdłuż ul. Puławskiej oraz przez ul. Srebrną wzdłuż ul. Towarowej w Warszawie),

- 2 na wyniesionych skrzyżowaniach przez 2 pasy ruchu (przejście przez ul. Niedziałkowskiego na skrzyżowaniu z ul. Skłodowskiej-Curie w Radomiu oraz przejścia przez dwa ramiona skrzyżowania ulic Klimczaka i Teodorowicza w Warszawie).

Widoczny był znaczący wpływ fizycznych środków uspokojenia ruchu oraz przekroju jezdni na zachowanie kierowców. Na wyniesione skrzyżowania i przejścia, pełniące funkcję progów spowalniających, wjeżdżało szybko 3\% kierowców. Na przejście w poziomie jezdni o przekroju 1x2 (szerokość na przejściu ok. 6,2 m) czterokrotnie więcej (12\%), a na przejście w poziomie jezdni o przekroju 1x3 (szerokość na przejściu 13-16m) ponad pięciokrotnie więcej (19\%) (ryc. 8).

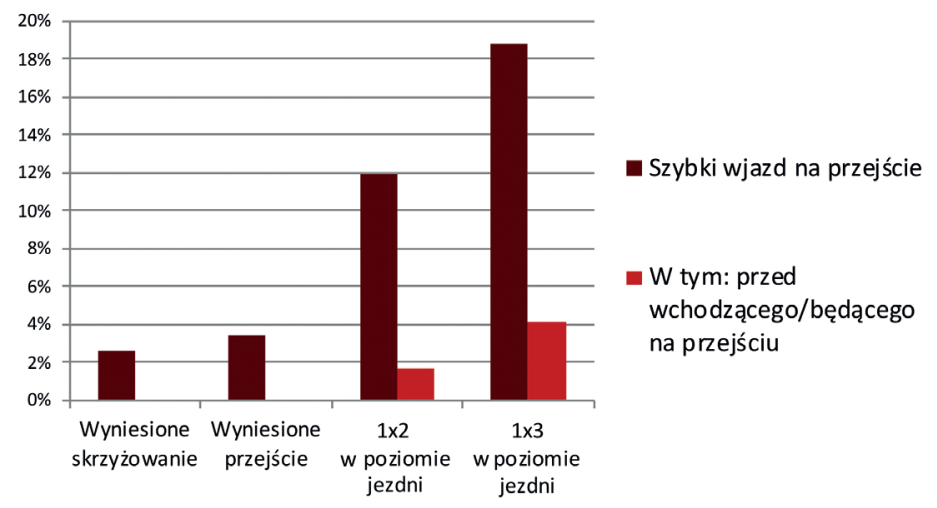

Ryc. 8. Częstotliwość szybkiego wjeżdżania na przejście na skrzyżowaniu typu „T" przez jezdnie o różnym przekroju i wyposażeniu 
Istotne znaczenie miały też promienie łuków na skrzyżowaniu. W przypadku samochodów skręcających w prawo, z drogi z pierwszeństwem, na przejście przez ul. Nowolipki szybko wjeżdżało 80\% kierowców, na przejście przez ul. Matejki-14\%. Dodatkowymi czynnikami mogącymi wpływać na zróżnicowane zachowanie kierowców były różnice w szerokości pasa ruchu (4,1 m a 3,1 m na początku przejścia) i oddalenie przejścia od skrzyżowania (ryc. 9), jak też obecność przejazdu dla rowerzystów w ciagu Al. Ujazdowskich. Ten ostatni skłaniał do bardziej ostrożnej jazdy ze względu na obowiązek ustapienia pierwszeństwa rowerzyście jadącemu na wprost. Natężenie ruchu niezmotoryzowanych było w obu przypadkach podobne, acz w ciagu Al. Ujazdowskich zdecydowanie wyższy był udział rowerzystów.
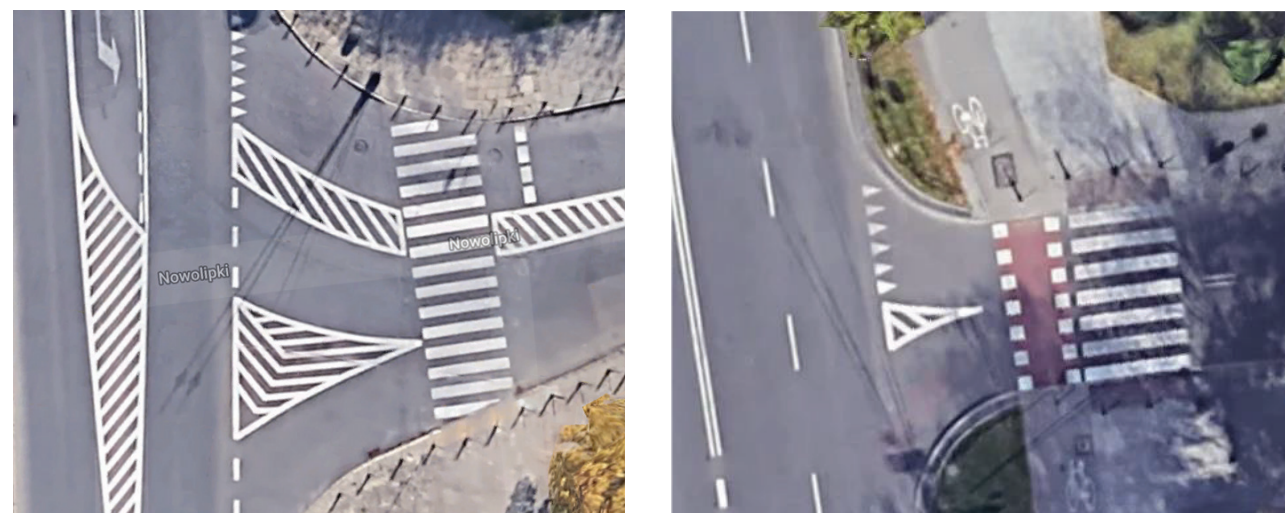

Ryc. 9. Przejścia przez ul. Nowolipki (po lewej) i ul. Matejki (po prawej) w Warszawie Źródło: Mapy Google

Obecność przejazdu dla rowerzystów w połączeniu z wyniesieniem przejścia i przejazdu skutkowała wysokim odsetkiem kierowców wyraźnie rozglądających się przed wjazdem (ok. 75\% na ulicach Srebrnej i Wędrowców). Był to zdecydowanie wyższy odsetek niż na skrzyżowaniu z przejazdem, ale bez wyniesienia (46\%). Niską skuteczność samego oznakowania poziomego potwierdził też sposób wykorzystania powierzchni wyłączonej z ruchu na przejściu przez ul. Nowolipki, przy Komendzie Stołecznej Policji, gdzie była ona wykorzystywana do omijania pieszych będących na przejściu, bez zatrzymywania samochodu, a nawet autobusu. W części przypadków skutkowało to koniecznościa przyspieszania lub zatrzymywania się pieszych (ryc. 10). W sumie, na ul. Nowolipki na przejście, na którym znajdowali się niezmotoryzowani, wjeżdżała większość kierowców, w tym 40\% bez zatrzymywania (ryc. 11).

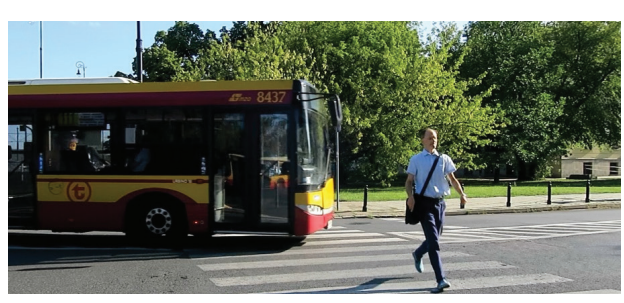

Ryc. 10. Autobus wjeżdżający bez zwalniania na przejście przez ul. Nowolipki w Warszawie przez powierzchnię wyłączoną z ruchu Fot. M. Sulmicki 


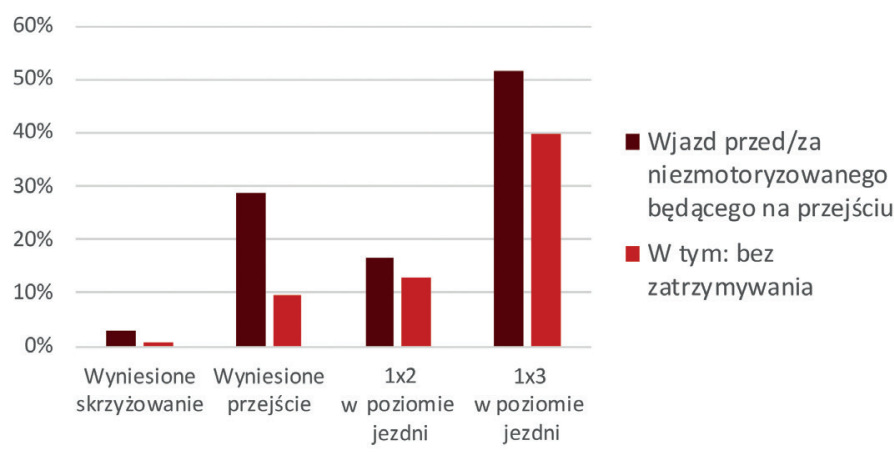

Ryc. 11. Częstotliwość wjeżdżania na przejście, na którym znajduje się niezmotoryzowany, na skrzyżowaniu typu "T" przez jezdnie o różnym przekroju i wyposażeniu

Źródło: opracowanie własne

Widoczna jest korelacja między przekrojem jezdni oraz środkami uspokojenia ruchu a faktycznym ustępowaniem pierwszeństwa pieszemu. Różnice w zachowaniu względem niezmotoryzowanych na przejściu/przejeździe widoczne były nawet w przypadku pojazdów nauki jazdy (ryc. 12 i 13). W przypadku dwupasmowych jezdni, odnotowano wyższy udział samochodów wjeżdżających na wyniesione przejście i przejazd niż na te w poziomie jezdni. Można to częściowo wyjaśnić zbliżonymi prędkościami poruszania się samochodów i niezmotoryzowanych wynikającymi z fizycznego uspokojenia ruchu. Efekt wyniesienia przejścia był zbliżony do przestrzeni współdzielonej, której założeniem jest płynny ruch naprzemienny wszystkich uczestników ruchu. Takie przypuszczenie potwierdzają wspomniany wysoki udział kierowców wyraźnie rozglądających się przed wjazdem na wyniesione przejście i przejazd oraz śladowy udział kierowców wjeżdżających na nie szybko.

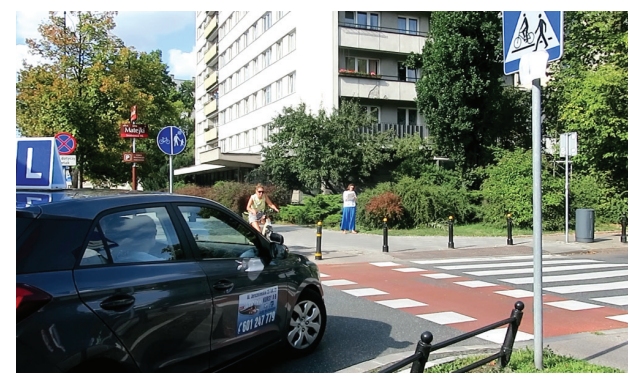

Ryc. 12. Samochód nauki jazdy ustępujący rowerzystce wjeżdżającej na przejazd przez ul. Matejki w Warszawie

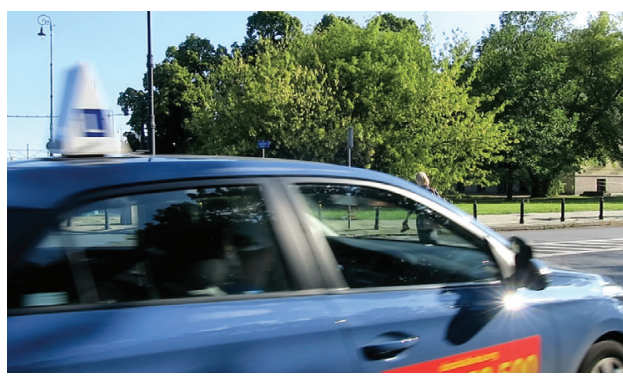

Ryc. 13. Samochód nauki jazdy wjeżdżający szybko za pieszego przechodzącego przez ul. Nowolipki w Warszawie

Fot. M. Sulmicki 


\subsection{Przejścia dla pieszych przez skrzyżowania z sygnalizacją świetlną}

Przejścia przez skrzyżowania z sygnalizacją zostały wybrane, biorąc pod uwagę możliwość warunkowego skrętu (zieloną strzałkę), typ skrzyżowania (trzy/czteroramienne) i obecność azyli dla pieszych. W związku z tym do badań wybrane zostały 4 przejścia przez skrzyżowania w Warszawie i 1 w Radomiu:

- 2 przez skrzyżowania trójramienne ze strzałką (przejście i przejazd z azylem przez ul. Nowy Zjazd wzdłuż Wybrzeża Kościuszkowskiego oraz przejście bez azylu przez ul. Sierakowskiego wzdłuż al. Solidarności w Warszawie - w drugim przypadku badano też zachowanie kierowców skręcających w prawo na przejście przez al. Solidarności na zielonym świetle),

- 2 przez skrzyżowania czteroramienne ze strzałką (przejścia z azylami przez ul. Nugat i Rosoła w Warszawie oraz bez azyli przez ul. 25 czerwca i Żeromskiego w Radomiu),

- 1 przez skrzyżowanie czteroramienne bez strzałki (przejście i przejazd z azylem przez al. Rzeczypospolitej na skrzyżowaniu z ul. Klimczaka w Warszawie).

Obserwacje potwierdziły wyniki innych badań, że czerwone światło z dopuszczalnym warunkowym skrętem w prawo jest traktowane domyślnie jako zielone światło. Choć wcześniejsze badania wskazywały, że do obowiązku zatrzymania się stosuje się ok. 1\% kierowców [Głowacka i in. 2010, s. 630-631], na obserwowanych skrzyżowaniach zatrzymywało się 22\% kierowców, przy czym większość z nich robiła to z powodu obecności niezmotoryzowanych. Gdy paliło się czerwone światło z dopuszczalnym warunkowym skrętem, ale na przejściu i przy nim nie było niezmotoryzowanych, na przejście bez zatrzymywania wjeżdżało $93 \%$ kierowców.

Istotna część kierowców wjeżdżała szybko na przejście na czerwonym świetle z dopuszczonym warunkowym skrętem. Odsetek ten wynosił 22\%, nie uwzględniając skrzyżowania w Radomiu, gdzie natężenie ruchu wynosiło ok. 1000 poj./h, co utrudniało rozwijanie większych prędkości. Widoczny był przy tym wpływ poszerzenia pasa ruchu i obecności pasa rozbiegowego na prędkość: na ul. Nugat (pas ruchu: 3,5 m) szybko na przejście wjeżdżało $8 \%$ kierowców, na Nowym Zjeździe (pas ruchu: 4,5 m) - 26\%, czyli ponad trzykrotnie więcej (ryc. 14 i 15).
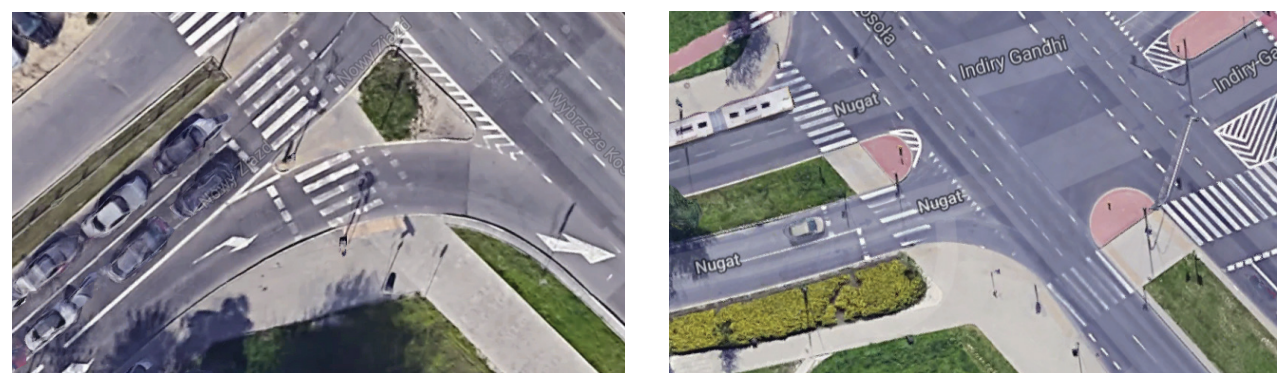

Ryc. 14 i 15 . Widok z góry na skrzyżowania ul. Nowy Zjazd i Wybrzeża Kościuszkowskiego oraz ulic Nugat i Rosoła

Źródło: Mapy Google 
Działo się tak mimo obecności przejazdu rowerowego na Nowym Zjeździe, czyli konieczności ustapienia rowerzystom jadącym drogą z pierwszeństwem i mających zielone światło, oraz ograniczonej widoczności z powodu samochodów czekających na pasach do jazdy na wprost. Choć promień łuku był w obu przypadkach ten sam, na Nowym Zjeździe zaczynał się przed przejściem dla pieszych. W połączeniu z obecnościa pasa rozbiegowego za przejściem, skutkowało to częstym rozpędzaniem się przed przejściem, by wjechać na nie szybko, mimo czerwonego światła.

Widoczny był silny związek pomiędzy przekrojem i szerokością jezdni a wjeżdżaniem przez kierowców na przejście, na którym jest pieszy (ryc. 16). W przypadku przejść przez ul. 25 Czerwca i ul. Żeromskiego w Radomiu oraz ul. Sierakowskiego w Warszawie (po 4-5 pasów ruchu), na zejście pieszego z pasów nie czekało niemal 2/3 kierowców (ryc. 17). Była to wartość 3,5-krotnie wyższa niż w przypadku przejścia przez jeden, ale szeroki pas ruchu (pas do skrętu na ul. Nowy Zjazd oraz pas wzdłuż peronu autobusowo-tramwajowego w al. Solidarności). Niemniej, również w tych przypadkach szeroki pas ruchu zachęcał 18\% kierowców do nieczekania na zejście pieszego z pasów. W przypadku przejścia przez dwa pasy ruchu, co czwarty kierowca wjeżdżał na przejście, z którego jeszcze nie zszedł pieszy (ryc. 18). Im jezdnia była węższa, w tym większej części takich przypadków pieszy był przynajmniej bliski zejścia/w trakcie schodzenia z jezdni.

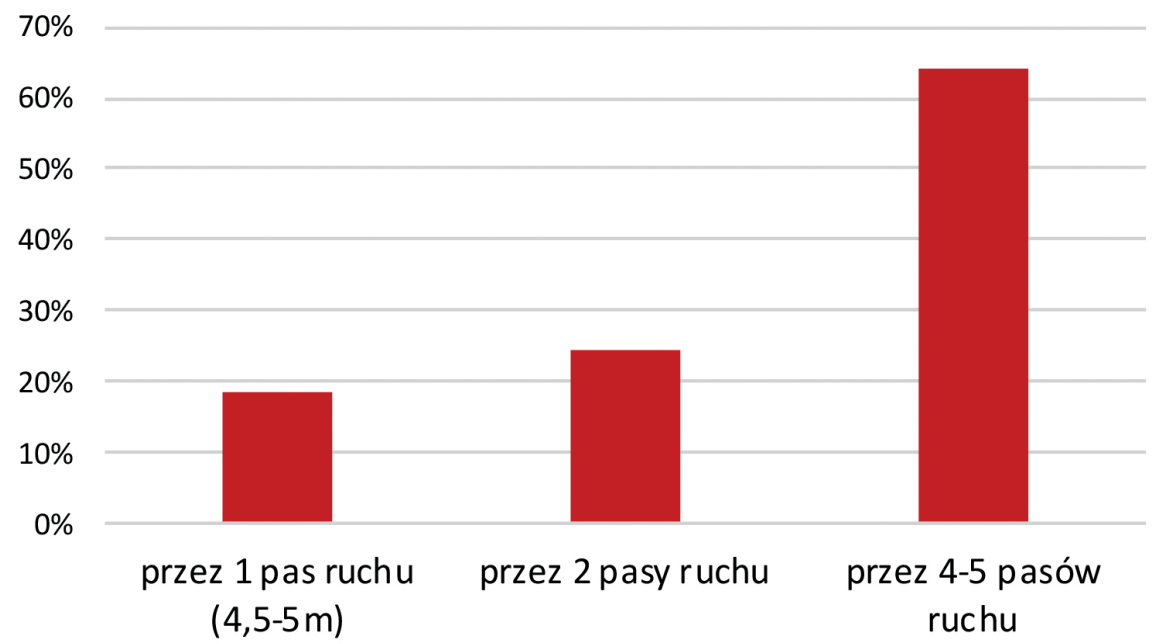

Ryc. 16. Częstotliwość wjeżdżania na skrzyżowaniu z sygnalizacją świetlną na przejście, na którym znajduje się niezmotoryzowany, przez jezdnie o różnym przekroju 


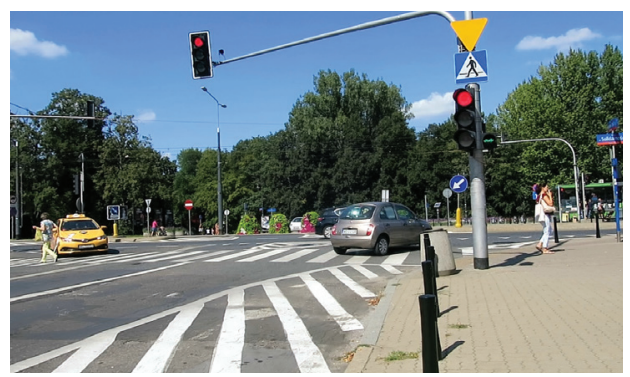

Ryc. 17. Samochody wjeżdżające na przejście, na którym znajduje się pieszy, na ul. Sierakowskiego w Warszawie

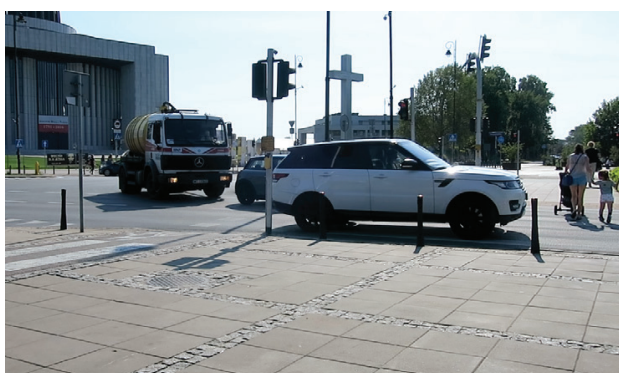

Ryc. 18. Samochody wjeżdżające na przejście, na którym znajdują się piesi, w al. Rzeczypospolitej w Warszawie

Fot. M. Sulmicki

Dodatkowym problemem generowanym przez możliwość warunkowego skrętu na czerwonym świetle było częstsze wjeżdżanie na przejście dla pieszych (skrzyżowanie) bez możliwości zjazdu z niego. Na 3 skrzyżowaniach z zieloną strzałka, gdzie badane były prawoskręty (Nowy Zjazd, Sierakowskiego, Nugat), 12\% kierowców stawało na pasach - dwa razy więcej niż na skrzyżowaniach typu „T" bez sygnalizacji (ryc. 19). Obecność zielonej strzałki skutkowała przy tym nie tylko nieprzestrzeganiem obowiązku zatrzymania się na czerwonym świetle $\mathrm{z}$ dopuszczonym warunkowym skrętem, lecz również obowiązku zatrzymywania się na czerwonym świetle w ogóle. Spośród skręcających w prawo na widocznych światłach, $10 \%$ wjeżdżało na żółtym lub czerwonym świetle bez zielonej strzałki, niektórzy nawet 30 sekund po zapaleniu się czerwonego, traktując samą obecność sygnalizatora S-2 jako zwolnienie z obowiązku zwracania uwagi na sygnalizacje przy prawoskręcie.

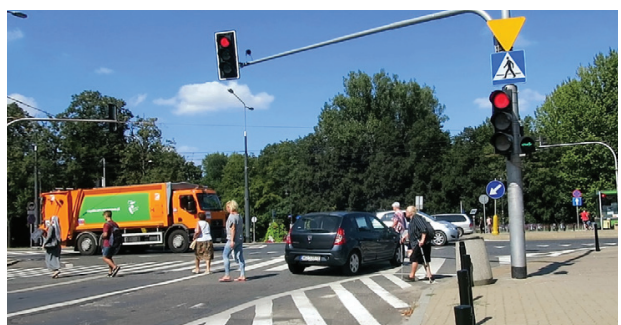

Ryc. 19. Samochód stojący na przejściu, na które wjechał na czerwonym świetle 2-3 sekundy po zgaśnięciu zielonej strzałki, na ul. Sierakowskiego w Warszawie

Fot. M. Sulmicki

\subsection{Przejścia dla pieszych przez ramiona rond}

Przejścia przez ramiona rond zostały wybrane, biorąc pod uwagę średnicę ronda, średnicę wyspy centralnej oraz przekrój jezdni na przejściu dla pieszych. W związku z tym do badań wybrane zostały 2 przejścia na rondach w Warszawie i 1 w Radomiu:

- 2 rondach średnich o średnicy 42 m, 25-28-metrowej wyspie i dwupasmowych wlotach/ wylotach (przejście przez wschodnie ramię ronda Żegańska/ Dworcowa w Warszawie oraz przejście i przejazd przez południowo-wschodnie ramię ronda Dmowskiego w Radomiu), 
- 1 na jednopasmowym rondzie małym o średnicy 24 m, 14-metrowej wyspie i jednopasmowych wlotach/wylotach (przejście i przejazd przez południowo-zachodnie ramię ronda Klimczaka/Sarmacka w Warszawie).

Wszystkie przejścia wyposażone były w azyle.

Widoczny był korzystny wpływ rozwiązania jednopasmowego na płynność ruchu pieszych - nie zdarzały się sytuacje, w których piesi musieli czekać na przejście. Na średnim rondzie na przejście musiała czekać 1 / 8 niezmotoryzowanych. Większa pewność niezmotoryzowanych była skorelowana z wyższą czujnością kierowców. Na rondzie jednopasmowym, większość kierowców rozglądała się przed wjazdem na przejście/przejazd. Na średnim rondzie dwupasmowym, kierowcy patrzyli przed siebie, na jezdnię, mimo że na rondzie w Radomiu również wyznaczone było zarówno przejście, jak i przejazd dla rowerzystów.

Podobnie jak w pozostałych przypadkach, większa liczba pasów ruchu na przejściu zmniejszała prawdopodobieństwo zatrzymania się kierowcy przed przejściem, do którego zbliżał się, lub na które wchodził niezmotoryzowany. Na rondzie dwupasmowym zatrzymywali się głównie kierowcy jadący pasem, od którego strony zbliżał się pieszy lub rowerzysta. Część jadących drugim pasem wyprzedzała wtedy na przejściu dla pieszych, stwarzając zagrożenie i skłaniając pieszych do czekania przed wejściem na przejście, aż zatrzymają się samochody na obu pasach (ryc. 20).
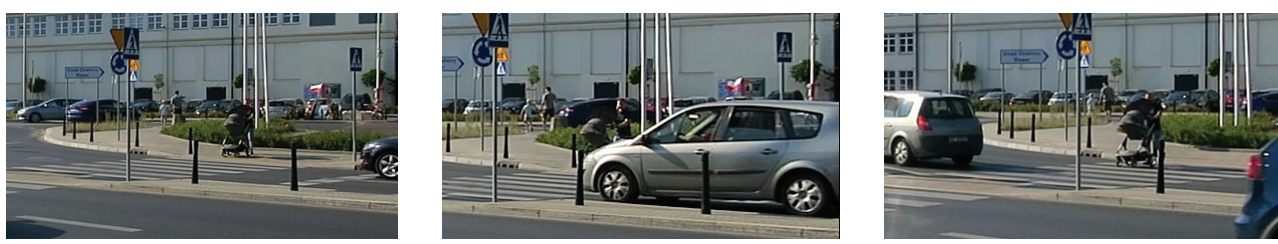

Ryc. 20. Wyprzedzanie samochodu przepuszczającego pieszego z wózkiem, gdy ten wchodzi na przejście przez ul. Żegańską w Warszawie

Fot. M. Sulmicki

Zachowanie kierowców na rondach potwierdziło również, że ponadnormatywnie szerokie pasy ruchu skłaniaja do wjeżdżania na przejście, na którym jest pieszy. W przypadku małego ronda, pasy ruchu miały przekrój 4,5-metrowy, mimo że zgodnie z przepisami w przypadku małych i mini rond dopuszczalne są jezdnie o metr węższe (ryc. 21). W efekcie, na przejście, mimo

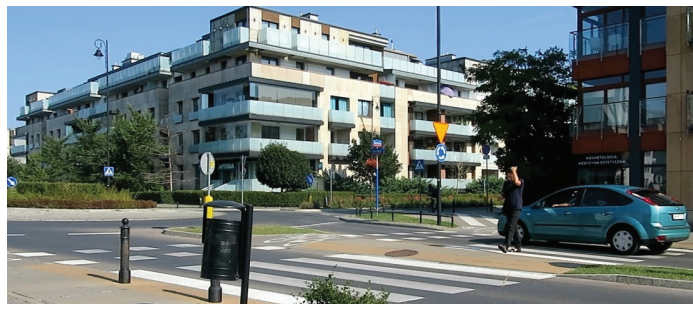

Ryc. 21. Samochód wjeżdżający za pieszego na przejściu przez ul. Klimczaka w Warszawie

Fot. M. Sulmicki obecności lub wchodzenia pieszego, wjeżdżała 1 / 3 kierowców - analogicznie do rond średnich (2 pasy ruchu o łącznej szerokości $7 \mathrm{~m})$, przy czym na rondach średnich odbywało się to z większą prędkością. 


\section{Wnioski}

Wyniki badań wskazuja, że:

- zapisy w dokumentach strategicznych i planistycznych województwa mazowieckiego słusznie wskazują na potrzebę stosowania fizycznych środków uspokojenia ruchu,

- zapisy te powinny być transponowane do dokumentów i praktyki na poziomie lokalnym,

- poprawa w zakresie bezpieczeństwa ruchu drogowego wymaga ujednolicenia podejścia do projektowania infrastruktury dla niezmotoryzowanych w myśl uszczegółowionych zapisów dokumentów wojewódzkich,

- wyniesione przejścia powinny być rozwiązaniem domyślnym w przypadku przejść wzdłuż drogi z pierwszeństwem przez drogę podporządkowana, tak by podkreślić pierwszeństwo poruszających się na wprost względem skręcających $\mathrm{w}$ droge podporządkowaną lub z niej wyjeżdżających,

- wyniesione skrzyżowania i małe/mini ronda powinny być rozwiązaniem domyślnym w przypadku skrzyżowań dróg niższych klas,

- przekrój jezdni na przejściu dla pieszych powinien być ograniczony do minimum,

- przepisy dotyczące pierwszeństwa pieszych przy wchodzeniu na przejście powinny zostać ujednoznacznione i ujednolicone, tak by kierujący pojazdem miał obowiązek ustąpić pierwszeństwa pieszemu zbliżającemu się do przejścia i wchodzącemu na nie, analogicznie do obowiązku ustąpienia pierwszeństwa pojazdowi nadjeżdżającemu droga z pierwszeństwem ${ }^{6}$; badania wykazały, że liczba sytuacji, w których kierowca wjeżdża przed pieszego wchodzącego na przejście jest trzyipółkrotnie wyższa, niż gdy pieszy jest już na przejściu (gdzie jego pierwszeństwo już teraz jest jednoznaczne).

Ponadto, należy mieć na uwadze następujące wnioski:

- $\quad$ wyniesione przejścia i przejazdy są zdecydowanie skuteczniejszym sposobem na uspokojenie ruchu w miejscu potencjalnych kolizji z niezmotoryzowanymi od zwykłej organizacji ruchu (wprowadzanej jedynie za pomocą oznakowania),

- nadmierny przekrój jezdni zachęca do wjeżdżania na przejście, na którym znajduje się pieszy; dotyczy to również szerszych pojedynczych pasów ruchu,

- $\quad$ ruch pieszy jest bardziej płynny na skrzyżowaniach bez sygnalizacji,

- na skrzyżowaniach z sygnalizacją wcześniejsze zapalenie się zielonego dla pieszych niż kolizyjnej zielonej strzałki pozwala ograniczyć liczbę sytuacji, w której kierowca wjeżdża na przejście, gdy wchodzi na nie pieszy,

- czerwone światło z dopuszczoną możliwością warunkowego skrętu jest traktowane przez kierowców jako zielone światło,

- przejazdy dla rowerzystów, na których kierowca ma obowiązek ustapić pierwszeństwa, zwiększają czujność kierowców i skutkują bardziej ostrożną jazdą; efekt ten może zostać zniweczony przez sygnalizację świetlną (w szczególności zielone strzałki) oraz geo-

\footnotetext{
${ }^{6}$ Według projektu zmiany ustawy Prawo o ruchu drogowym z 30 stycznia 2020 r. (nr UD 53 w wykazie prac legislacyjnych i programowych Rady Ministrów), kierowca ma ustapić pieszemu wchodzącemu na przejście, lecz pieszy ma pierwszeństwo dopiero, gdy znajdzie się na pasach.
} 
metrię i oznakowanie (np. dwupasmowy wylot ze znakiem „ustap pierwszeństwa” za przejazdem na rondzie w Radomiu),

- brak jednoznacznych przepisów dotyczących pierwszeństwa pieszych na przejściach zaburza płynność ruchu ze względu na brak zaufania zarówno ze strony kierowców, jak i pieszych, którzy nie mogą być pewni, kiedy kierowca ustapi im pierwszeństwa; skutkuje to czekaniem, aż kierowca całkowicie zatrzyma się na jezdni, przed wejściem na przejście. Efekt ten jest szczególnie widoczny na przejściach przez więcej niż jeden pas ruchu.

\section{Literatura}

Budzyński M., Jamroz K., Mackun T., 2017, Pedestrian Safety in Road Traffic in Poland, 2017, IOP Conf. Series: Materials Science and Engineering, 245 042064, s. 1-9.

Głowacka J., Kidawa J., Sierpiński G., 2010, Ocena warunków ruchu w sytuacji zastosowania sygnału dopuszczajacego skręcanie w kierunku wskazanym strzałka dla wybranych skrzyżowań z sygnalizacja świetlnq w Katowicach, Logistyka, 2, s. 621-632.

Ministerstwo Infrastruktury, Sekretariat Krajowej Rady Bezpieczeństwa Ruchu Drogowego, 2019, Badania zachowań pieszych i relacji pieszy-kierowca wrzesień-grudzień 2018 r., Warszawa.

Skoczyński P., Wacowska-Ślęzak J., 2019, Bezpieczeństwo ruchu drogowego w Polsce w 2018 roku. Analiza danych o wypadkach drogowych, Polskie Obserwatorium Bezpieczeństwa Ruchu Drogowego, http://www.obserwatoriumbrd.pl/resource/c17a26eb-a594-48c3-bf3eb71717392b9b:JCR.

Vaa T., 2006, Understanding driver/pedestrian conflicts: Driver behaviour and effect of measures at pedestrian crossings, 19th ICTCT Workshop. Proceedings, Section 3, s. 1-11.

\section{Akty prawne i dokumenty}

Rozporządzenie Ministrów Infrastruktury oraz Spraw Wewnętrznych i Administracji z dnia 31 lipca 2002 r. w sprawie znaków i sygnałów drogowych (Dz.U.2019.0.2310).

Plan zagospodarowania przestrzennego województwa mazowieckiego, przyjęty Uchwałą nr 22/ / 18 Sejmiku Województwa Mazowieckiego z dnia 19 grudnia 2018 r.

Projekt ustawy o zmianie ustawy - Prawo o ruchu drogowym oraz ustawy o kierujących pojazdami z dnia 30 stycznia $2020 \mathrm{r}$.

Strategia rozwoju Obszaru Metropolitalnego Warszawy do roku 2030, 2015, metropolia warszawska, omw.um.warszawa.pl

Strategia rozwoju województwa mazowieckiego do 2030 roku. Innowacyjne Mazowsze, przyjęta Uchwałą nr 158/13 Sejmiku Województwa Mazowieckiego z dnia 28 października 2013 r. 


\section{The impact of infrastructure on driver behavior at pedestrian crossings Warsaw and Radom case study}

\section{ABSTRACT}

In 2019 driver behavior was observed at pedestrian and bicycle crossings in order to identify the impact of infrastructure thereupon. The main goal of the study was to verify the accuracy of the strategic and spatial planning documents of the Mazovia Region concerning road safety. The sites observed in Warsaw and Radom were chosen so that they would include all the forms of traffic calming on pedestrian crossings indicated in the Spatial development plan of Mazovia, taking into consideration such aspects as road width, intersection layout and traffic lights.

The observations focused on the behavior of drivers towards pedestrians and cyclists, as well as behavior which determined whether the driver would be able to react to the appearance of a non-motorized road user. The observation points were located at a certain distance from the intersection, so as not to influence the road users' behavior. On the basis of at least 30-minute observations and recordings, the following types of driver behavior were analyzed: stopping before pedestrian/bicycle crossings, driving in front of/ behind a non-motorized road user, stopping on the crossing, driving onto the crossing without slowing down. In certain locations, the drivers were also observed in terms of looking both ways before driving through the crossing. However, such observations were often not possible due to high traffic intensity and/or inadequate visibility. The observations in Radom were carried out by Sebastian Pawłowski and Łukasz Zaborowski from the Radom branch of the Mazovian Office of Regional Planning.

A study of the observations allows for the following factors influencing drivers' risky behavior to be identified: the width of the road on the crossing, the presence of a bicycle crossing and the rules concerning right of way, as well as the presence and type of traffic lights. Hatched areas indicated only through road markings were found to be ineffective, as were red lights with the conditional permission to turn right after stopping (green arrows) which were treated by drivers as green lights.

The study confirmed the accuracy of the provisions of the Mazovian strategic and spatial planning documents, along with the need to implement them more systematically. An analysis of the observation results allowed for the identification of the impact of certain parameters of infrastructure on driver behavior which is complementary to earlier local studies as well as the 2018 national studies.

Key words: road safety, pedestrian crossings, unprotected road users, traffic calming

\footnotetext{
Maciej Sulmicki, dr - główny specjalista w Mazowieckim Biurze Planowania Regionalnego, członek stowarzyszenia Zielone Mazowsze, adiunkt w Akademii Finansów i Biznesu Vistula. Specjalizuje się w problematyce transportu zgodnego z zasadami trwałego rozwoju, ze szczególnym naciskiem na ruch pieszy i rowerowy; kontakt do autora: Mazowieckie Biuro Planowania Regionalnego, ul. Nowy Zjazd 1, 00-301 Warszawa, e-mail:msulmicki@mbpr.pl

Maciej Sulmicki, PhD - key specialist in the Mazovian Office for Regional Planning, member of the Green Mazovia Association, lecturer at Vistula University. Specializes in sustainable transport, with particular emphasis on pedestrian and bicycle traffic. Contact: Mazovian Office for Regional Planning, ul. Nowy Zjazd 1, 00-301 Warszawa, e-mail:msulmicki@mbpr.pl
} 